\title{
ANALISIS FAKTOR-FAKTOR PENYEBAB MIGRASI PENDUDUK JAWA AKIBAT PERTUMBUHAN PENDUDUK YANG TINGGI
}

\author{
Oleh: \\ Ainun Cahya \\ Email : aiinun1680@gmail.com \\ Pendidikan IPS \\ Fakuktas Keguruan Dan Ilmu Pendidikan \\ Universitas Lambung Mangkurat
}

\begin{abstract}
Abstrak
Dinamika kependudukan menjadi salah satu aspek yang harus diperhatikan dalam perencanaan wilayah. Kependudukan penting untuk diperhatikan dan menjadi bahan pertimbangan dikarenakan penduduk merupakan subjek sekaligus objek pembangunan guna mencapai kesejahteraan. Migrasi merupakan salah satu dari tiga faktor dasar yang mempengaruhi pertumbuhan penduduk, selain kelahiran (fertilitas) dan kematian (mortalitas). Migrasi dapat meningkatkan jumlah penduduk apabila jumlah penduduk yang masuk ke suatu wilayah lebih banyak daripada jumlah penduduk yang meninggalkan wilayah tersebut. Penelitian ini mengkaji lebih dalam dinamika migrasi penduduk yang terjadi di pulau Jawa. Penelitian ini menggunakan metode kuantitatif dengan penelitian mengguanakan Studi Literatur. Tujuan penelitian ini adalah untuk mengetahui faktor penyebab terjadinya migrasi penduduk jawa.
\end{abstract}

Kata Kunci : Migrasi, Penduduk, Ekonomi, dan Wilayah

\section{Pendahuluan}

Pembangunn ekonomi merupakan proses dinamis yang dalam jangka menengah atau panjang akan membawa dampak perubahan strukural dan transformasi ekonomi. Tujuan pembangunan meliputi kenaikan pendapatan perkapita yang relatif cepat, ketersediaan kesempatan kerja yang luas, distribusi pendapatan yang merata, serta kemakmuran antar daerah. Namun kenyataannya masih besar distribusi pendapatan dan pembangunan yang tidak merata yang mengakibatkan terjadi pengingkatan angka kesenjangan ekonomi yang semakin tinggi, 
baik antar pusat dan daerah, antar masing-masing daerah, antar golongan, dan di seluruh aspek yang membuat struktur perekonomian yang tidak kokoh.

Sesuai dengan tujuan utama migrasi yaitu untuk meningkatkan taraf hidup migran dan keluarganya, sehingga pada umumnya mereka bermigrasi untuk mencari pekerjaan yang dapat memberikan pendapatan dan status sosial yang lebih tinggi di daerah tujuan. Sehubungan dengan pesatnya pertumbuhan ekonomi suatu daerah, sebagai contoh pertumbuhan ekonomi yang tinggi di pulau Jawa merupakan penyebab meningkatnya jumlah penduduk migran yang masuk ke daerah lain seperti kalimantan. Selain itu Jawa yang merupakan daerah paling berkembang sektor industrinya dibanding daerah lain di Indonesia menjadi daerah tujuan utama migran luar Jawa untuk migrasi ke daerah tersebut. Hal ini dikarenakan, sektor industri yang merupakan salah satu faktor penggerak dalam pertumbuhan ekonomi, menjadi faktor penarik bagi migran yang berharap mendapat kesempatan kerja yang lebih baik. Yang menjadi rumusan masalah dalam penelitian ini adalah pertama, faktor-faktor apa yang mempengaruhi tingkat migrasi internal keluar pulau jawa. Kedua, Seberapa penting faktor tersebut dalam mempengaruhi keputusan bermigrasi keluar pulau jawa. Tujuan penelitian ini adalah melihat perkembangan migrasi keluar pulau jawa.serta menganalisis faktor-faktor yang mempengaruhi terjadinya migrasi keluar pulau jawa. Sesuai dengan permasalahan yang dikemukakan diatas maka dapat dirumuskan hipotesa bahwa diduga migrasi disebabkan oleh faktor ekonomi seperti upah riil yang lebih tinggi di daerah tujuan, Pertumbuhan ekonomi yang lebih tinggi daerah tujuan yang menjadi daya tarik bagi migran . Selain itu arus migrasi ini dapat mengganggu keseimbangan pasar kerja yang ada di daerah tujuan seperti terjadinya kelebihan penawaran tenaga kerja di daerah tujuan.

\section{Metode Penulisan}

Metode yang digunakan dalam penelitian ini adalah berawal dari banyaknya asumsi bahwa alasan pertama membuat seseorang melakukan migrasi karena alasan faktor ekonomi yang menjadi tanggapan seorang migran terhadap perbedaan pendapatan dan kurangnya lapangan pekerjaan akibat kepadatan penduduk yang tinggi alasan seseorang bermigran atau berpindah dari tempat satu ke tempat yang lain. Metode pengumpulan data menggunakan metode Kuantitatif dengan menggunakan studi literatur dimana pengumpulannya menggunakan teoriteori dan menelususri sumber-sumber terpercaya seperti jurnal, artikel dan buku untuk 
mendapatkan informasi yang lebih relevan sesuai dengan fakta lapangan yang benar-benar terjadi, hal itu dibuktikan dengan macam-macam metode yang diambil oleh penulis itu sendiri.

\section{Pembahasan}

\section{A. Pengertian Migrasi Penduduk}

Warga Negara adalah penduduk sebuah negara atau bangsa berdasarkan keturunan, tempat kelahiran, dan sebagainya, yang mempunyai kewajiban dan hak penuh sebagai warga negara itu. memiliki domisili atau tempat tinggal tetap di suatu wilayah negara, yang dapat dibedakan menjadi warga negara asli dan warga negara asing (WNA). Menurut pasal 26 UUD 1945 (1) Yang menjadi warga negara ialah orang-orang bangsa Indonesia asli dan orang-orang bangsa lain yang disahkan dengan undang-undang sebagai warga negara. (2) Penduduk ialah warga negara Indonesia dan orang asing yang bertempat tinggal di Indonesia. (3) Hal-hal mengenai warga negara dan penduduk diatur dengan undang-undang.Menurut pasal 26 ayat (2) UUD 1945,Penduduk adalah warga negara Indonesia dan orang asing yang bertempat tinggal di Indonesia. Bukan Penduduk, adalah orang-orang asing yang tinggal dalam negara bersifat sementara sesuai dengan visa Istilah Kewarganegaraan (citizenship) memiliki arti keanggotaan yang menunjukkan hubungan atau ikatan antara negara dengan warga negara, atau segala hal yang berhubungan dengan warga negara. Menurut Kartomo Wirosuhardjo Penduduk ialah sejumlah orang yang mendiami sebuah wilayah tertentu, disebut penduduk terlepas dari status warga negara. Sedangkan Menurut P.N.H. Simanjuntak Penduduk merupakan sekumpulan orang yang menempati sebuah wilaya sebagai tempat tinggal yang berdomisili disuatu negara.

Menurut Martin (2003) menyatakan migrasi adalah perpindahan penduduk dari satu daerah ke daerah lain, yang terjadi karena adanya perbedaan kondisi kedua daerah tersebut. Perbedaan terbesar yang mendorong terjadinya migrasi adalah kondisi ekonomi dan non ekonomi. Sedangkan dalam arti luas, migrasi merupakan perubahan tempat tinggal secara permanen atau semi permanen (Tjiptoherijanto, 2009). Dalam pengertian yang demikian tersebut tidak ada pembatasan baik pada jarak perpindahan maupun sifatnya, serta tidak dibedakan antara migrasi dalam negeri dengan migrasi luar negeri (Lee, 2011). Sejarah kehidupan suatu bangsa selalu diwarnai dengan adanya migrasi, dan oleh karena itu pula 
terjadi proses pencampuran darah dan kebudayaan. Migrasi juga dapat diartikan sebagai perubahan tempat tinggal seseorang baik secara permanen maupun semi permanen, dan tidak ada batasan jarak bagi perubahan tempat tinggal tersebut (Lee, 2011). Proses migrasi internal dan internasional terjadi sebagai akibat dari berbagai perbedaan antara daerah asal dan daerah tujuan. Perbedaan ini disebabkan oleh faktor ekonomi, sosial dan lingkungan.

Berdasarkan teori-teori tersebut terlihat bahwa tujuan utama migrasi adalah meningkatkan taraf hidup migran dan keluarganya, sehingga masalah migrasi masih dipandang sebagai suatu hal yang positif dalam pembangunan ekonomi. Namun, fakta yang terjadi di negara berkembang berbeda dengan pandangan tersebut, dimana arus migrasi tenaga kerja dari pedesaan yang umumnya bekerja pada sektor pertanian jauh melampaui tingkat penciptaan atau penambahan lapangan pekerjaan khususnya sektor industri atau jasajasa layanan sosial di perkotaan. Kehadiran para pendatang tersebut cenderung melipat gandakan tingkat penawaran tenaga kerja di perkotaan, sementara persediaan tenaga kerja yang sangat bernilai di pedesaan semakin tipis. Kedua, di sisi permintaan, penciptaan kesempatan kerja didaerah perkotaan lebih sulit dan jauh lebih mahal daripada penciptaan lapangan kerja di pedesaan karena kebanyakan jenis pekerjaan sektor-sektor industri di perkotaan membutuhkan aneka inputinput komplementer yang sangat banyak jumlah maupun jenisnya. Indonesia sebagai salah satu negara berkembang juga mengalami kondisi yang demikian

\section{B. Sejarah Awal Mula migrasi Penduduk}

Perpindahan penduduk ke atau dari Pulau Jawa telah terjadi sejak abad ke-18 Masehi atau bahkan abad-abad sebelumnya . Asal usul suku-suku bangsa yang ada di Indonesia yang berasal dari Hindia Belakang serta dataran Indo-China menggarisbawahi suatu hipotesis yang menyatakan bahwa perpindahan penduduk merupakan salah satu ciri yang dijumpai dalam perkembangan peradaban umat manusia. Pada masa pasca masuknya agama Islam ketika peradaban umat manusia telah berkembang relatif maju, perpindahan penduduk masih terus berlangsung. Sudah barang tentu sifat atau faktor penyebab terjadinya pergerakan penduduk itu berbeda dari satu masa dengan masa yang lain. Dalam masyarakat kerajaan Mataram Lama, yang merupakan masyarakat tradisional Jawa yang tipikal, digambarkan oleh Gonggrijp (1957) bahwa kehidupan masyarakat pedesaan dalam suasana tertekan dan 
serba kekurangan merupakan pendorong bagi terjadinya perpindahan penduduk. Karena eksploitasi yang dilakukan oleh penguasa dan penjahat sedemikian hebat, tidak ada dorongan bagi masyarakat desa untuk berproduksi dan untuk memperoleh surplus. Suasana kehidupan masyarakat kecil di pedesaan yang tertindas selama beberapa generasi diduga keras sebagai penyebab munculnya tata nilai yang menjadi corak kehidupan masyarakat kecil pedesaan Jawa yang tepa slira, tidak ingin mengungguli dalam hal pemilikan barang dari sesama warga desanya, yaitu yang dikenal dengan konsep leveling-off mechanism (Sanders, 1967).

Konsep tepa slira 56 atau kemauan untuk hidup sama-sama miskin yang seakan-akan dipaksa oleh situasi yang diciptakan oleh sistem sosial itu pada situasi lain justru menjadi suatu kemampuan bagi ekonomi rakyat kecil sebagaimana suatu strategi dalam menghadapi himpitan hidup yang seakan-akan tidak lepas dari mereka atau self defence mechanis yang diperkenalkan oleh Geertz (1963) dengan istilah shared poverty. Tekanan atau beban yang harus disangga oleh penduduk pedesaan pada masyarakat tradisional bukan saja berasal dari penguasa dari tingkat atas sampai penguasa di tingkat bawah. Kedatangan bangsa Eropa di Nusantara yang ingin mengeksploitasi tanah dan penduduk menambah masalah di pedesaan Jawa semakin kompleks. Mekanisme beladiri dalam menghadapi kesulitan hidup yang tidak tertahankan lagi adalah dengan melakukan perpindahan ke daerah lain, meskipun fenomena tersebut sering dipertanyakan orang. Dengan berpindah tempat berarti seseorang harus meninggalkan tempat yang telah dihuni beberapa lama, tempat tinggal, serta lahan garapan untuk menopang hidupnya. Untuk memperoleh itu semua di tempat yang baru, seseorang harus mengeluarkan tenaga dan biaya tidak sedikit, yang hampir tidak mungkin bagi penduduk pedesaan untuk memperolehnya. Kenyataannya, sejak awal abad ke-18 sampai dengan awal abad ke- 20, di Jawa telah terjadi perpindahan penduduk yang berlangsung secara sporadis (lihat Heeren, 1979, Warsito, 1994, Swaso- no, 1984).

Fenomena perpindahan penduduk yang terjadi itu menunjukkan adanya pola tertentu. Salah satu di antara pola perpindahan itu lebih merupakan fenomena sosial yang dilakukan oleh orang atau sekelompok orang dengan motivasi pribadi atau kelompok untuk mencari penghidupan yang lebih baik. Pola yang lain adalah lebih bermuatan politik, yang berupa program perpindahan penduduk secara terencana, yang dilaksanakan oleh pemerintah 
seperti pengerahan tenaga kerja untuk perkebunan pada masa penjajahan Belanda pada awal abad ke-20 sampai pelaksanaan program transmigrasi pada masa kemerdekaan. Sementara itu, terdapat ragam yang lain, yaitu percampuran antara pola perpindahan penduduk secara spontan dengan perpindahan yang diatur. Secara konseptual, selama dua abad terakhir, ekologi pedesaan memang telah berubah, baik secara sosial dan kultural (Kartodirdjo, 1992) maupun secara sosiologis-agronomis (Sajogya dan Sajogya, 1974). Dalam dinamika perubahan yang didorong oleh kekuatan internal dan eksternal itu ternyata petani lapisan bawah yang miskin tetap menjadi objek dan menjadi kelompok yang tersisih dalam pergulatan politik yang terjadi, baik di tingkat nasional maupun tingkat lokal.

\section{Faktor-Faktor Penyebab Penduduk Melakukan Migrasi}

Berdasarkan pengelompokannya, maka faktor yang mendorong migran untuk migrasi dibedakan dalam tiga kategori, yaitu faktor demand pull, supply push dan network. Faktor demand pull terjadi jika ada permintaan tenaga kerja dari daerah tujuan Faktor supply push terjadi jika tenaga kerja sudah tidak mungkin lagi memperoleh pekerjaan di daerahnya sendiri, sehingga mendorong mereka untuk migrasi ke daerah lain. Network factor merupakan faktor yang dapat memberi informasi bagi migran dalam mengambil keputusan untuk migrasi.

Menurut (Adioetomo dan Samosir, 2011) mengatakan Faktor-faktor yang mempengaruhi masyarakat Pulau Jawa melakukan Migrasi ke berbagai daerah terbagi menjadi dua yaitu faktor pendodorng dan faktor penarik, adapun penejelasaannya sebagai berikut:

- Faktor Pendorong ini lebih mengacu pada faktor-faktor yang dimiliki wilayah asalnya yang menyebabkan masyarakat meninggalkan wilayah asalnya, adapaun alasannya yaitu:

1. Kurangnya lapangan pekerjaan

2. Kurangnya sarana dan prasarana

3. Menurunnya sumber daya alam yang dimiliki wilayah asalnya tersebut.

- Faktor penarik ini merupakan faktor-faktor yang menyebabkan penduduk melakukan perpindahan ke daerah tujuan tersebut alasannya yaitu: 
1. Tersedianya lapangan pekerjaan

2. Kelengkapan sarana dan prasarana

3. Ketersediaan fasilitas pelayanan publik yang baik

4. Hidup lebih terjamin karena sumber daya alam yang masih baik

Sementara Lee (1970) membedakan faktor-faktor yang mempengaruhi terjadinya migrasi dibagi menjadi empat bagian yaitu:

1. Faktor-faktor yang terdapat didaerah asal

2. Faktor-faktor terdapat di daerah tujuan

3. Penghalang antara

4. faktor individu

\section{Peran Pemerintah Dalam Mengatasi penyebab Penduduk Jawa Melakukan Migrasi}

Menurut Haris (2002) Aktivitas migrasi yang berlangsung dari wilayah satu ke wilayah tertentu merupakan imbas positif yang berkembang sebagai konsekuensi pertumbuhan ekonomi daerah yang bersangkutan. Kepadatan penduduk yang tinggi adalah hal utama penyebab terjadinya migrasi penduduk jawa keluar daerah, selain faktor pendorong dan faktor penarik penyebab perpindahan penduduk dari satu wilayah ke wilayah lainnya. Akibat kepadatan penduduk inilah yang menjadi akar permasalahan banyaknya dampak yang diakibatkan dari masalah tersebut. Seperti yang kita ketahui, penduduk indonesia ada lebih 300 kelompok etnik atau suku bangsa indonesia yaitu 1.300 suku menurut sensus BPS tahun 2010. Suku jawa adalah kelompok terbanyak dan terbesar di indonesia dengan jumlah mencapai $41 \%$ dari total populasi. Sedangkan luas pulau jawa yang memungkinkan tidak dapat memuat banyak penduduk menyebabkan banyaknya permukiman kumuh dan penebangan hutan terjadi akaibat kepadatan penduduk jawa ini menyebabkan pulau jawa seringkali mengalami bencana seperti banjir akibat dari penggundulan hutan dan pembuangan sampah sembarangan masyarakat yang tidak bisa diatasi menyebabkan sungaisungai yang ada di pulau jawa menjadi tercemar dan tersumbatnya air yang membuat banjir sering terjadi dimana-mana.

Peran pemerintah dalam mengatasi pertumbuhan penduduk pulau jawa yang sangat menigkat tersebut dengan mengadakan program KB (Keluarga Berencana) pada keluarga 
untuk mengurangi angka kelahiran yang tinggi, juga salah satunya mengadakan program transmigrasi kepada masyarakat pulau jawa. Transmigrasi merupakan program yang dibuat pemerintah indonesia untuk memindahkan penduduk dari suatu daerah ke daerah lain di dalam wilayah indonesia dengan tujuan mengurangi kepadatan penduduk yang terjadi di pulau jawa, seperti penduduk jawa dipindahkan ke daerah Kalimantan yang jarang penduduk. Dari peran pemerintah tersebut dapat mengatasi terjadinya banyak masalah yang akan terjadi apabila pemerintah hanya membiarkan masyarakatnya melakukan kehidupan tanpa tata tertib, hal yang memungkinkan dan bahkan di prediksi sudah terjadi akibat dari kepadatan penduduk dan pertumbuhan penduduk yang sangat tinggi tersebut adalah banyaknya permukiman kumuh, banyaknya pengangguran, tingginya amgka kriminalitas dan banyaknya kemiskinan dimana-mana akibat dari pertumuhan yangat tinggi yang tidak bisa di atasi tersebut.

\section{Simpulan}

Migrasi merupakan proses perpindahan penduduk dari satu tempat ke tempat yang lain yang produk marjinal sosialnya nol ke produk marjinal sosialnya bukan hanya positif, tetapi juga akan dan dapat meningkat sehubungan dengan adanya peningkatan modal dan kemajuan teknologi. Migrasi sirkuler merupakan solusi dari salah satu faktor penting untuk membangun ekonomi desa. Migrasi sirkuler dapat berdampak positif dan negatif. Dampak yang ditimbulkan tidak hanya dalam segi ekonomi, melainkan juga dari segi sandang, pangan, papan, pendidikan, kesehatan, dan infrastuktur desa. Pembangunan ekonomi Indonesia secara merata akan tercapai, baik di desa maupun di kota.

\section{Referensi}

Adinda, M. Analisis Faktor-Faktor Yang Mempengaruhi Tingkat Migrasi Tenaga Kerja Wanita Keluar Negeri (Studi Kasus Pada 4 Daerah Industri di Jawa Barat) (Bachelor's thesis, Fakultas Ekonomi dan Bisnis uin jakarta).

Indahri, Y. (2017). Tantangan Pengelolaan Penduduk di Kota Surabaya. Aspirasi: Jurnal Masalah-masalah Sosial, 8(1), 1-11. 
Julianto, D., \& Alfian, A. (2017). ANALISIS FAKTOR-FAKTOR YANG MEMPENGARUHI TINGKAT MIGRASI KELUAR SUMATERA BARAT. Jurnal Ekonomi dan Bisnis Dharma Andalas, 19(2), 164.

Nisa, K. Analisis Faktor-Faktor Yang Mempengaruhi Tingkat Migrasi Tenaga Kerja Indonesia (Tki)(Studi Kasus Pada 6 Provinsi Tahun 2008-2017)(Bachelor's thesis, Fakultas ekonomi dan bisnis uin jakarta).

Ompusunggu, V. M. (2018). Analisis Dampak Migrasi Dalam Meningkatkan Pertumbuhan Ekonomi Keluarga Desa (Studi Pada Desa Tanjung Gusti, Kecamatan Galang, Kabupaten Deli Serdang, Sumatera Utara). Ekonomikawan: Jurnal Ilmu Ekonomi dan Studi Pembangunan, 18(2).

Padmo, S. (1999). Perpindahan Penduduk dan Ekonomi Rakyat Jawa, 19001980. Humaniora, 11(3), 56-66.

Purnomo, D. (2009). Fenomena migrasi tenaga kerja dan perannya bagi pembangunan daerah asal: studi empiris di kabupaten wonogiri. Jurnal Ekonomi Pembangunan: Kajian Masalah Ekonomi Dan Pembangunan, 10(1), 84-102.

Ramadhany, M. N. (2021). ANALISIS FAKTOR-FAKTOR YANG MEMPENGARUHI TINGKAT MIGRASI KELUAR MASYARAKAT KABUPATEN/KOTA DI PULAU MADURA. Jurnal Ilmiah Mahasiswa FEB, 9(2).

Rochaida, E. (2016, June). Dampak Pertumbuhan Penduduk Terhadap Pertumbuhan Ekonomi dan Keluarga Sejahtera di Provinsi Kalimantan Timur. In Forum Ekonomi (Vol. 18, No. $1)$. 